\title{
Atorvastatin Has no Effects on Kidney Tissues of Wistar Albino Rats in the Long-Term Intake: An Electron Microscopic Study
}

\author{
Atorvastatina no Tiene Efectos sobre los Tejidos Renales de Ratas Wistar Albinas \\ en el Consumo a Largo Plazo: Un Estudio de Microscopia Electrónica
}

"Ayfer Aktas; "M. Serhan Tasdemir; *"M. Cudi Tuncer; "Yusuf Nergiz; "Murat Akkus, \& ****Hüsnü Alper Bagriyanik

AKTAS, A; TASDEMIR, M. S.; TUNCER, M. C.; NERGIZ, Y.; AKKUS, M. \& BAGRIYANIK, H. A. Atorvastatin has no effects on kidney tissues of Wistar albino rats in the long-term intake: An electron microscopic study. Int. J. Morphol., 29(1):144-150, 2011.

SUMMARY: In this study, we evaluated the ultrastructural findings of kidney with systemic administration of different doses of atorvastatin in a rat model. Statins may have anti-inflammatory effects that would play a role in preventing the cellular damage. The aim of this study was to investigate how atorvastatin could play a role in kidney tissues. Forty adult male Wistar albino rats (200-250 g) were randomly divided into 4 groups of ten rats each (A1, A2, A3 and Control). Three different doses of atorvastatin were used to determine the effects on kidney tissues during 90 day period. The kidneys of A1 (0.1-mg group), A2 (0.5-mg group) and A3 (1-mg group) group were excised and the tissues were examined after the 90 days by transmission electron microscopy. Despite increasing the dose of atorvastatin intake, the histological structures of atorvastatin groups were appeared normal in the same period. In conclusion, long-term use of atorvastatin was not found to have an adverse effect on kidney tissue.

KEY WORDS: Kidney; Wistar-albino rat; Statins; Atorvastatin; Ultrastructural.

\section{INTRODUCTION}

Experimental evidence suggest that lipids are important of progressive renal disease. In recent years, the inhibitors of 3-hydroxy-3-methylglutaryl coenzyme (HMGi-CoA) reductase, so called "statins", have demonstrated beneficial effects in the different models of progressive renal failure. Statins have been used frequently in experimental studies (Zhang et al., 2006; Sabbatini et al., 2004; Gianella et al., 2007; Agarwal, 2007; Gueler et al., 2002; Oda \& Keane, 1999; Chen et al., 2008). Statins, or 3-hydroxy-3-methylglutaryl-coenzyme A reductase inhibitors, are used clinically for their cholesterol-lowering properties (Sacks et al., 1996). The roles of statins in coronary artery disease are well reported. Some studies have focused on the mechanisms involved in the antiinflammatory effects of statins (Dunzendorfer et al., 1997; Wong et al., 2001; Patel \& Corbett, 2003; Patel \& Corbett,
2004). Due to their favorable effects on lipid levels and cardiovascular outcome, 3-hydroxy-3-methylglutarylcoenzyme A (HMG-CoA) reductase inhibitors have been commonly used after kidney transplant. Recent studies have demonstrated that statins have pleiotropic effects unrelated to lipid levels including reduced inflammation, improved endothelial function, and improved insulin sensitivity (Goicoechea et al., 2006; Collins et al., 2006; Yoshimura et al., 1998). The incidence of chronic renal diseases is increasing worldwide, and there is a great need to identify therapies capable of arresting or reducing disease progression. The current treatment of chronic nephropathies is limited to angiotensin converting enzyme inhibitors and angiotensin receptor blockers, but there is growing clinical and experimental evidence that statins could play a therapeutic role. In experimental studies,

\footnotetext{
* Department of Histology and Embryology, Faculty of Medicine, Dicle University, Diyarbakir, Turkey

** Department of Anatomy, Faculty of Medicine, Dicle University, Diyarbakır, Turkey.

**** Department of Histology and Embryology, Faculty of Medicine, Dokuz Eylül University, Izmir, Turkey.
} 
beneficial effects of atorvastatin on chronic allograft nephropathy (Zhang et al.), improving ischemic acute renal failure in aging rats (Sabbatini et al.), preventing kidney inflamation and in fibrosis in stoke-prone rats (Gianella $e t$ al.; Gueler et al.) have been shown in vivo animals models. Except for atorvastatin in statins, lovastatin ameliorated the extent of glomerular injury in 5/6 nephrectomy SpragueDawley rats (Kasiske et al., 1988), obese Zucker rats (O'Donnell et al., 1993), Dahl-sensitive rats (O'Donnell et al., 1992), guinea pigs and promycin aminonucleo-side model of the nephrotic syndrome (Harris et al., 1990). Simvastatin suppressed the cell proliferation in rats with antiThy-1.1 nephritis (Yoshimura et al.).

In light of these informations, we aimed to evaluate atorvastatin effects on rats without any kidney disease in ultrastructural level.

\section{MATERIAL AND METHOD}

Animals. Adult male albino Wistar rats weighing 250 to $300 \mathrm{~g}$ were used in this experimental study. All rats were given standard rat chow and tap water ad libitum. This study was carried out according to the principles of the Declaration of Helsinki.

Experimental Conditions. On the first study day, the rats were randomly divided into 4 groups: the atorvastatin 0.1 , $0.5,1.0-\mathrm{mg}$ groups and the control group. All the rats were housed in the same room, which was $7 \mathrm{~m} 3$ in size, and were kept at $20^{\circ} \mathrm{C}\left( \pm 2^{\circ} \mathrm{C}\right)$ under a 12-hour light/dark regimen in stainless steel cages.

Atorvastatin Preparation and Administration. During 90 day period, the atorvastatin groups received $0.1,0.5$ and $1.0 \mathrm{mg} / \mathrm{kg} / \mathrm{d}$ of atorvastatin dissolved in $2 \mathrm{ml}$ methyl cellulose solution and the control group received $2 \mathrm{ml}$ of methyl cellulose solution alone. Dosages of atorvastatin were administered orally in $5 \mathrm{ml}$ per $\mathrm{kg}$ of body weight of each rat.

Procedure. The rats were euthanized using ether anesthesia. The kidneys were excised and fixed in $2.5 \%$ phosphate-buffered glutaraldehyde for histopathologic evaluation. Samples of semithin cross-sections of the lung tissues were prepared with an ultramicrotome, stained with toluidine blue, and examined using a photomicroscope. After the selection of appropriate specimens, the tissues, which were stained with uranyl citrate and lead acetate, were screened by transmission electron microscopy (TEM) (Carl Zeiss Libra 120 EFTEM, Germany).

\section{RESULTS}

Fourty adult male albino Wistar rats were divided into 4 groups of 10 rats each. All rats survived the 90-day study period. Groups were identified as A1 (0.1-mg group), A2 (0.5-mg group), A3 (1-mg group) and Control.

Physiological effects of Atorvastatin. During 90-day study period, all dosages of atorvastatin had no effect on food or fluid intake, and body weight.

Atorvastatin 0.1, 0.5 and 1.0-mg Groups. Electron microscopy showed normal histologic appearance of the foot processes or villous transformation of podocytes in the glomeruli of Wisstar albino rat's given all atorvastatin groups. The podocytes showed no degenerative changes, including extensive villous transformations, cell shape abnormalities, and, notably, focal detachment of the foot processes. Strikingly, no podocyte detachment was found in the glomeruli of the atorvastatin given rats, which indicates preserved cell interactions with the underlying glomerular basement membrane (Figs. B, C and D). As a result, no significant differences were observed between the different doses of atorvastatin during long-term administration. When the thin sections of microphotographs of group A1, A2 and A3 compared with the control group showed a normal histologic structure in any of the atorvastatin groups. None of the atorvastatin groups had pathologies such as interstitial cell infiltration, fibrosis, vascular congestion and hemorrhage (Figs. B, C and D). These data suggest that atorvastatin has no devastating effect on kidney morphology and does not lead to any kidney ailment in the long-term intake. Besides well known benefits of statins on the cardiovascular system and chronic kidney diseases, the absence of any adverse effect of atorvastatin on kidney tissue is a clinically significant finding.

Control Group. The thin section of microphotograph of the control group showed that glomerular podocyte cells, glomerular filtration, capillary endothelium, proximal and distal tubules, mitochondrions and mikrovilli in apical, appeared normal (Fig. A).

\section{DISCUSSION}

In this experimental study, we aimed to put forward long-term intake of atorvastatin and changes in kidney tissue in ultrastructural level. According to our findings, we determined that atorvastatin had no effets on kidney tissue in the long-term. Considering a broad range of use of statins 

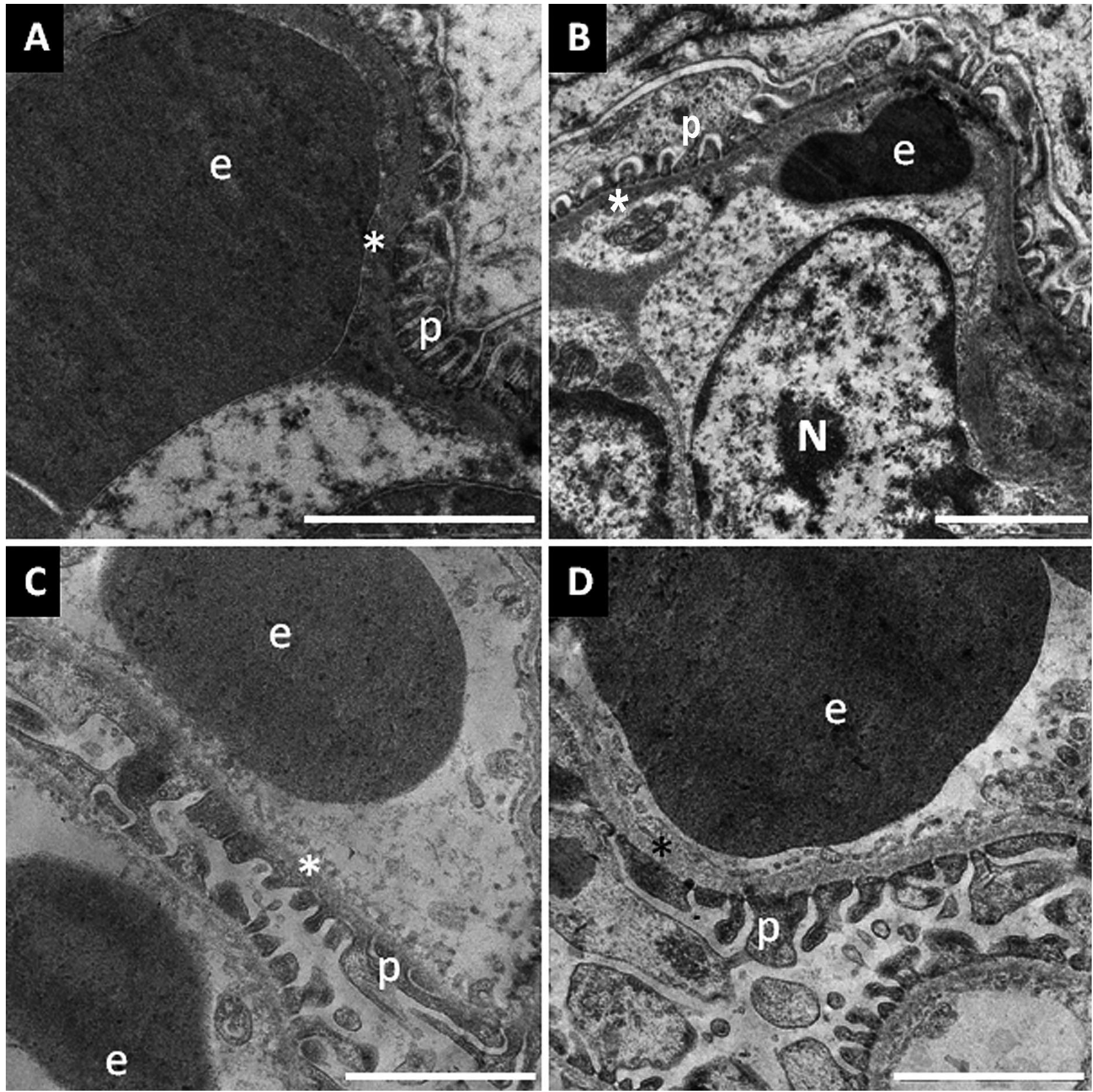

Fig. A. High magnification of kidney tissue of rats in the control group showing erythrocyte cell (e), basal membran (*), pedicels (p), (bar:2000nm). Figs. B, C, D. High magnification of kidney tissue of rats in the atorvastatin 0.1-mg group (Figure B), $0.5 \mathrm{mg}$ group (Figure C) and $1.0 \mathrm{mg}$ group (Figure C) showing erythrocyte cell (e), nucleus (N), basal membran (*) and pedicels (p), (bar:2000nm).

in humans for preventing disorders, this is a very important finding for experimental and human studies to be carried out.

Statins lower serum cholesterol levels and may therefore be expected to reduce lipid deposits in the kidney. Nevertheless, the exact mechanism by which statins protect against renal damage is unclear. Statins inhibit the ratelimiting enzyme (HMG-CoA reductase) in cholesterol synthesis, but inhibition of this enzyme also leads to downstream inhibition of the synthesis of the isoprenoids farnesyl pyrophosphate and geranyl pyrophosphate (Epstein \& Campese, 2005; Blanco-Colio et al., 2003). These isoprenoids normally attach to intracellular signaling proteins to facilitate a variety of cellular responses, including gene expression, membrane trafficking, cell proliferation and migration, and programmed cell death. By blocking isoprenoid synthesis, statins produ- 
ce an array of antiinflammatory and vascular effects that are independent of cholesterol reduction. For example, stem cells govern numerous ischemic and degenerative disorders, and recent investigations have shown that statins may play a role in modulating stem cell function (Romagnani et al., 2007). Similarly, impaired endothelial progenitor cell function is characteristic of vascular injury, and statin therapy may improve the regenerative capacity of progenitor cells (Walter et al., 2004).

It has been generally accepted that hyperlipidemia is involved in the pathophysiological mechanisms that accelerate progression of renal failure so lowering LDL cholesterol level and triglicerides by statins may be beneficial for the kidney. Lipid deposition can directly damage the glomerular basement membrane. It can also stimulate mesangial cell activation and proliferation, a process similar to smooth muscle cell proliferation in the evolution of atherosclerotic plaque (Kasiske et al., 1990; Agarwal \& Curley, 2005). Mesangial cells then release chemokines that recruit monocytes to the mesangium, where they are transformed into resident macrophages that secrete proinflammatory and profibrotic mediators capable of augmenting the proliferative process (Rovin \& Tan, 1993; Pai et al., 1995; Guijarro et al., 1995). The macrophages also ingest lipids to become foam cells, which are commonly detected at early stages of glomerulonephritis. Each of these cell types is capable of producing reactive oxygen species that oxidize LDL. Oxidized LDL, in turn, can cause further monocyte recruitment, endothelial dysfunction, and mesangial cell cytotoxicity (Guijarro et al.; Kamanna et al., 1996; Tashiro et al., 1999). Analogous pathophysiological mechanisms have been proposed to operate in glomerulosclerosis and atherosclerosis (Diamond, 1991). In diseases ranging from glomerulonephritis and hypertension, renal damage frequently leads to cellular proliferation mainly mesangial (O'Donell et al., 1993) and epithelial cells (Vrtovsnik et al., 1997), that triggers a chronic mechanism which can cause permanent loss of nephrons. Statins inhibit proliferation, and this effect could be of therapeutic value in kidney diseases. They also promote apoptosis that mediates the resolution of glomerular hypercellularity and glomerular scarring in experimental mesangial proliferative nephritis (Buemi et al., 1999). Buemi et al. (2000) observed that fluvastatin lowered proteinuria in $\operatorname{IgA}$ nephropathy.

In the studies of ischemia reperfusion, the results of their study demonstrated that in aging rats, pretreatment with atorvastatin mitigates the course of ischemic acute renal failure by blunting the more pronounced negative response to renal ischemia through a mechanism independent of cholesterol levels. Their data, moreover, suggested that the partial inhibition of Rho, the activation of eNOS, and the higher availability of $\mathrm{NO}$ after statin treatment play a major role in this protection, obtained in rats free of age-related nephropathy. Their data have important clinical implications in treating elderly patients with ischemic ARF and in preventing renal dysfunction due to renal hypoperfusion (Sabbatini et al.). Furthermore, Gueler et al. observed that statin treatment reduced damage in the $\mathrm{S} 3$ segment of proximal tubules in the outer medullary stripe, the area that is most susceptible to hypoperfusion and hypoxia. Untreated animals demonstrated typical changes in the $\mathrm{S} 3$ segment, namely loss of the brush border, destruction of epithelial cells, naked basement membranes, and tubular obstruction. Statin treatment clearly reduced the morphologic damage. Inflammatory reactions attributable to ischemia-reperfusion injury are characterized by leukocyte infiltration. They determined that a statin ameliorated post-ischemic acute renal failure. According to the results, inflammatory mechanisms were significantly affected, supporting the hypothesis that the statin exerted direct antiinflammatory effects in vivo. Cell infiltration, ICAM-1 and iNOS upregulation, matrix molecule expression, MAP kinase ERK1/ 2 activation, and transcription factor activation were all reduced.

In chronic kidney diseases, the results of Fasset et al. suggested that the effectiveness and safety of atorvastatin and establish its effects on oxidative stress and inflammation in patients with chronic kidney disease. The hypothesis was that atorvastatin $10 \mathrm{mg}$ would significantly slow the rate of decline of kidney function (eGFR) in subjects with chronic kidney disease (Fasset et al., 2008). In addition, a recent reanalysis of the Treating to New Targets (TNT) study revealed that atorvastatin improved GFR in 10,001 patients with chronic kidney disease. This effect was significantly greater in patients on high-dosage atorvastatin compared with those on low-dosage therapy (Shepherd et al., 2007). Beneficial effects of statins in various kinds of glomerulonephrititis have been largely reported in diabetic nephropathy (Casey et al., 2005), CsA nephrotoxicity (Kandoussi et al., 2002), unilateral ureteral obstruction rats (Mizuguchi et al., 2004); however, studies of its protection on CAN after kidney transplantation have not been fully explored. Zhang et al. presented that atorvastatin could prevent the progression of disease in the established rat model of chronic allograft nephropathy with F344 (Fisher kidneys) to Lewis rat recipients allograft kidney transplantation. The F344 (Fisher kidneys) to Lewis rat recipients model is a common model of chronic rejection between rat strains. The histological changes of this model are of great similarity with human kidney transplantation allografts.

A study showed that statin use was associated with reduced mortality rates in a large cohort of kidney transplant 
recipients (Wiesbauer et al., 2008). Previous trials have consistently demonstrated that statins reduce cardiovascular morbidity and mortality in the general population; however, in renal patients especially in renal transplant recipients the beneficial effects of statins are less well established. Welten et al. (2008) reported that statin use was associated with improved recovery from acute kidney injury after major surgery and had a beneficial effect on long-term survival.

It is worthwhile to mention that statins reduce mortality in uremic patients (Seliger et al., 2002). However, administration and dosing of statins to renal patients must be careful, particularly in renal impairment. Atorvastatin and fluvastatin have low renal excretion $(2 \%$ and $6 \%$ respectively) and should be preferred in patients with renal impairment. In mild to moderate renal insufficiency no dose adjustment of lovastatin and simvastatin is needed but the dose of these two statins should be lowered and administered cautiously. Pravastatin is excreted in $50 \%$ by the kidney and should be avoided in renal insufficiency (Sica \& Gehr, 2002).

In conclusion, we have shown that long-term atorvastatin intake in Wistar albino-rats without any kidney diseases has no effects on kidney morphology in ultrastructural level. In light of these experimental and human studies, we consider that these data can play an important role in the treatment of cardiovascular and immunological disorders in humans.

AKTAS, A; TASDEMIR, M. S.; TUNCER, M. C.; NERGIZ, Y.; AKKUS, M. \& BAGRYYANIK, H. A. Atorvastatina no tiene efectos sobre los tejidos renales de ratas Wistar albinas en el consumo a largo plazo: Un estudio de microscopía electrónica. Int. J. Morphol., 29(1):144-150, 2011.

RESUMEN: En un modelo de rata, se evaluaron los hallazgos ultraestructurales del riñón provocados por la administración sistémica de diferentes dosis de atorvastatina. Las estatinas pueden tener efectos anti-inflamatorios que desempeñan un importante rol en la prevención del daño celular. El objetivo de este estudio fue investigar cómo la atorvastatina podría desempeñar un papel en los tejidos del riñón. 40 Ratas Wistar albinas Adultas (200-250 g) machos fueron divididas aleatoriamente en cuatro grupos de 10 ejemplares cada uno (A1, A2, A3 y Control). Tres diferentes dosis de atorvastatina se utilizaron para determinar los efectos sobre los tejidos del riñón durante un período de 90 días. Los riñones de los grupos A1 (0,1 mg), A2 (0,5 mg) y A3 (1 mg) fueron extirpados a los 90 días y los tejidos examinados por microscopía electrónica de transmisión. A pesar de haberse aumentado la dosis de ingesta de atorvastatina, las estructuras histológicas se asemejaron al grupo normal del mismo período. En conclusión, el uso de atorvastatina en un plazo prolongado, no produce efecto negativo sobre el tejido renal.

PALABRAS CLAVE: Riñón; Ratas Wistar albinas; Estatinas; Atorvastatina; Ultraestructurales.

\section{REFERENCES}

Agarwal, R. Effects of Statins on Renal Function. Mayo Clin. Proc., 82:1381-90, 2007.

Agarwal, R. \& Curley, T.M. The role of statins in chronic kidney disease. Am. J. Med. Sci., 330:69-81, 2005.

Blanco-Colio, L. M.; Tuñón, J.; Martín-Ventura, J. L. \& Egido, J. Anti-inflammatory and immunomodulatory effects of statins. Kidney Int., 63:12-23, 2003.

Buemi, M.; Allegra, A.; Corica, F.; Ruello, A.; Aloisi, C.; Pettinato, G.; Giacobbe, M.; Romeo, A. \& Frisina, N. Effects of lisinopril administration on blood bcl-2 concentrations in patients with immunoglobulin A nephropathy. Clin. Pharmacol. Ther., 65:649-52, 1999.

Buemi, M.; Allegra, A.; Corica, F.; Aloisi, C.; Giacobbe, M.S.; Pettinato, G.; Corsonello, A.; Senatore, M. \& Frisina, N. Effect of fluvastatin on proteinuria in patients with IgA nephropathy. Clin. Pharmacol. Ther., 67:427$31,2000$.

Casey, R. G.; Joyce, M.; Roche-Nagle, G.; Chen, G. \& Bouchier-Hayes, D. Pravastatin modulates early diabetic nephropathy in an experimental model of diabetic renal disease. J. Surg. Res., 123:176-81, 2005.

Chen, G. P.; Yao, L.; Lu, X., LI, L. \& Hu, S. J. Tissue-specific effects of atorvastatin on 3-hydroxy-3 methylglutaryl coenzyme A reductase expression and activity in spontaneously hypertensive rats. Acta. Pharmacol. Sin., 29:1181-6, 2008.

Collins, P.; Ford, I.; Croal, B.; Ball, D.; Greaves, M.; Macaulay, E. \& Brittenden, J. Haemostasis, inflammation and renal function following exercise in patients with intermittent claudication on statin and aspirin therapy. Thromb. J., 4:9, 2006. 
Diamond, J. R. Analogous pathobiologic mechanisms in glomerulosclerosis and atherosclerosis. Kidney Int. Suppl., 31:S29-34, 1991.

Dunzendorfer, S.; Rothbucher, D.; Schratzberger, P.; Reinisch, N.; Kähler, C. M. \& Wiedermann, C. J. Mevalonate-dependent inhibition of transendothelial migration and chemotaxis of human peripheral blood neutrophils by pravastatin. Circ. Res., 81:963-9, 1997.

Epstein, M. \& Campese, V. M. Pleiotropic effects of 3hydroxy-3-methylglutaryl coenzyme a reductase inhibitors on renal function. Am. J. Kidney Dis., 45:2$14,2005$.

Fassett, R. G.; Ball, M. J.; Robertson, I. K.; Geraghty, D. P. $\&$ Coombes, J. S. The Lipid lowering and Onset of Renal Disease (LORD) Trial: a randomized double blind placebo controlled trial assessing the effect of atorvastatin on the progression of kidney disease. BMC Nephrol., 18:4, 2008.

Gianella, A.; Nobili, E.; Abbate, M.; Zoja, C.; Gelosa, P.; Mussoni, L.; et al. Rosuvastatin treatment prevents progressive kidney inflammation and fibrosis in strokeprone rats. Am. J. Pathol., 170(4):1165-77, 2007.

Goicoechea, M.; de Vinuesa, S. G.; Lahera, V.; Cachofeiro, V, Gómez-Campderá, F.; Vega, A.; et al. Effects of atorvastatin on inflammatory and fibrinolytic parameters in patients with chronic kidney disease. J. Am. Soc. Nephrol., 17:S231-5, 2006.

Gueler, F.; Rong, S.; Park, J. K.; Fiebeler, A.; Menne, J.; Elger, M.; et al. Postischemic acute renal failure is reduced by short-term statin treatment in a rat model. $J$. Am. Soc. Nephrol., 13:2288-98, 2002.

Guijarro, C.; Kasiske, B. L.; Kim, Y.; O’Donnel, M. P.; Lee, H. S. \& Keane, W. F. Early glomerular changes in rats with dietary-induced hypercholesterolemia. Am. J. Kidney Dis., 26:152-61, 1995.

Harris, K. P.; Purkerson, M. L.; Yates, J. \& Klahr, S. Lovastatin ameliorates the development of glomerulosclerosis and uremia in experimental nephrotic syndrome. Am. J. Kidney Dis., 15:16-23, 1990.

Kamanna, V. S.; Pai, R.; Roh, D. D. \& Kirschenbaum, M. A. Oxidative modification of low-density lipoprotein enhances the murine mesangial cell cytokines associated with monocyte migration, differentiation, and proliferation. Lab. Invest., 74:1067-79, 1996.
Kandoussi, A.; Martin, F.; Hazzan, M.; Noël, C.; Fruchart, J. C.; Staels, B.; et al. HMG-CoA reductase inhibition and PPAR- alpha activation both inhibit cyclosporin A induced endothelin-1 secretion in cultured endothelial cells. Clin. Sci. (London), 103:81S-3, 2002.

Kasiske, B. L.; O'Donnell, M. P.; Garvis, W. J. \& Keane, W. F. Pharmacologic treatment of hyperlipidemia reduces glomerular injury in rat $5 / 6$ nephrectomy model of chronic renal failure. Circ. Res., 62:367-74, 1988.

Kasiske, B. L; O’Donnell, M. P.; Schmitz, P. G.; Kim, Y. \& Keane, W. F. Renal injury of diet-induced hypercholesterolemia in rats. Kidney Int., 37:880-91, 1990.

Mizuguchi, Y.; Miyajima, A.; Kosaka, T.; Asano, T.; Asano, T.; \& Hayakawa, M. Atorvastatin ameliorates renal tissue damage in unilateral ureteral obstruction. J. Urol., 172:2456-9, 2004.

Oda, H. \& Keane, W. F. Recent advances in statins and the kidney. Kidney Int., 56:S2-5, 1999.

O'Donnell, M. P.; Kasiske, B. L.; Kim, Y.; Schmitz, P. G. \& Keane, W. F. Lovastatin retards the progression of established glomerular disease in obese Zucker rats. Am. J. Kidney Dis., 22:83-9, 1993.

O'Donnell, M. P., Kasiske, B. L.; Katz, S. A.; Schmitz, P. G. \& Keane, W. F. Lovastatin but not enalapril reduces glomerular injury in Dahl salt-sensitive rats. Hypertension, 20:651-8, 1992.

Pai, R.; Kirschenbaum, M. A. \& Kamana, V. S. Low-density lipoprotein stimulates the expression of macrophage colony-stimulating factor in glomerular mesangial cells. Kidney Int., 48:1254-62, 1995.

Patel, T. R. \& Corbett, S. A. Mevastatin suppresses lipopolysaccharide-induced Rac activation in the human monocyte cell line THP-1. Surgery, 134:306-11, 2003.

Patel, T. R. \& Corbett, S. A. Simvastatin suppresses LPSinduced Akt phosphorylation in the human monocyte cell line THP-1. J. Surg. Res., 116:116-20, 2004.

Romagnani, P.; Lasagni, L.; Mazzinghi, B.; Lazeri, E. \& Romagnani, S. Pharmacological modulation of stem cell function. Curr. Med. Chem., 14:1129-39, 2007.

Rovin, B. H. \& Tan, L. C. LDL stimulates mesangial fibronectin production and chemoattractant expression. Kidney Int., 43:218-25, 1993. 
Sabbatini, M.; Pisani, A.; Uccello, F.; Serio, V.; Serù, R.; Paternò, R.; et al. Atorvastatin improves the course of ischemic acute renal failure in aging rats. J. Am. Soc. Nephrol., 15:901-9, 2004.

Sacks, F. M.; Pfeffer, M. A.; Moye, L. A.; Rouleau, J. L.; Rutherford, J. D.; Cole, T. G.; et al. The effect of pravastatin on coronary events after myocardial infarction in patients with average cholesterol levels. Cholesterol and Recurrent Events Trial investigators. $N$. Engl. J. Med., 335:1001-9, 1996.

Seliger, S. L.; Weiss, N. S.; Gillen, D. L.; Kestenbaum, B.; Ball, A.; Sherrard, D. J.; et al. HMG-CoA reductase inhibitors are associated with reduced mortality in ESRD patients. Kidney Int., 61:297-304, 2002.

Sica, D. A. \& Gehr, T. W. 3-hydroxy-3-methylglutaryl coenzyme A reductase inhibitors and rhabdomyolysis: con- siderations in the renal failure patient. Curr. Opin. Nephrol. Hypertens., 11:123-33, 2002.

Shepherd, J.; Kastelein, J. J.; Bittner, V.; Deedwania, P.; Breazna, A.; Dobson, S.; et al. Effect of intensive lipid lowering with atorvastatin on renal function in patients with coronary heart disease: The Treating to New Targets (TNT) study. Clin. J. Am. Soc. Nephrol., 2:1131-9, 2007.

Tashiro, K.; Makita, Y.; Shike, T.; Shirato, I.; Sato, T.; Cynshi, O.; et al. Detection of cell death of cultured mouse mesangial cells induced by oxidized low-density lipoprotein. Nephron, 82:51-8, 1999.

Vrtovsnik, F.; Couette, S.; Prie, D.; Lallemand, D. \& Friedlander, G. Lovastatin-induced inhibition of renal epithelial tubular cell proliferation involves a p21ras activated, AP-1-dependent pathway. Kidney Int., 52:1016-27, 1997.

Walter, D. H.; Dimmeler, S. \& Zeiher, A. M. Effects of statins on endothelium and endothelial progenitor cell recruitment. Semin. Vasc. Med., 4:385-93, 2004.

Welten, G. M.; Chonchol, M.; Schouten, O.; Hoeks, S.; Bax, J. J.; van Domburg, R. T.; et al. Statin use is associated with early recovery of kidney injury after vascular surgery and improved long-term outcome. Nephrol. Dial. Transplant., 23:3867-73, 2008

Wiesbauer, F.; Heinze, G.; Mitterbauer, C.; Harnoncourt, F.; Hörl, W. H. \& Oberbauer, R. Statin use is associated with prolonged survival of renal transplant recipients. J. Am. Soc. Nephrol., 19:2211-8, 2008.
Wong, B.; Lumma, W. C.; Smith, A. M.; Sisko, J. T.; Wright, S. D. \& Cai, T. Q. Statins suppress THP-1 cell migration and secretion of matrix metalloproteinase 9 by inhibiting geranylgeranylation. J. Leukoc. Biol., 69:959-62, 2001.

Yoshimura, A.; Inui, K.; Nemoto, T.; Uda, S.; Sugenoya, Y.; Watanabe, S.; et al. Simvastatin suppresses glomerular cell proliferation and macrophage infiltration in rats with mesangial proliferative nephritis. J. Am. Soc. Nephrol., 9:2027-39, 1998.

Zhang, W.; Liu, M.; Wu, Y.; Zhu, P.; Yin, C.; Zhang, W.; et al. Protective effects of atorvastatin on chronic allograft nephropathy in rats. J. Surg. Res., 143:428-36, 2007.

Correspondence to:

Mehmet Cudi Tuncer

Department of Anatomy

Faculty of Medicine, Dicle University

Diyarbakır, Turkey

Tel: +90 4122488001 Ext. 4539

Fax: +90 4122242083

Email: drcudi@hotmail.com

Received: 24-09-2010

Accepted: 19-11-2010 